\title{
Maitotilayrityksen kokonaisvaltaisen johtamisen käsikirjan luominen T\&K -hankkeessa
}

\author{
Matti Ryhänen ${ }^{1)}$, Margit Närvä1), Timo Sipiläinen²) ja Jyrki Rajakorpi ${ }^{1)}$ \\ ${ }^{1)}$ Seinäjoen ammattikorkeakoulu, SeAMK Ruoka, PL 412, 60101 Seinäjoki \\ etunimi.sukunimi@seamk.fi \\ ${ }^{2)}$ Helsingin yliopisto, Taloustieteen osasto, PL 27, 00014 Helsingin yliopisto \\ timo.sipilainen@helsinki.fi
}

\section{TIIVISTELMÄ}

Maitotilayrityksen johtaminen on laaja-alainen tehtävä, joka ulottuu toimintojen ja tuotannonhaarojen tasolta koko maitotilayrityksen tasolle. Nykyaikaiselta maitotilayrittäjältä edellytetään vaativien tuotanto- ja johtamismenetelmien hallintaa. Maitotilayritystä on tarve johtaa strategisesti kokonaisuutena. Kokonaisvaltaisella johtamisella mahdollistetaan tuotantoprosessien ja toimintojen määrätietoinen ja systemaattinen johtaminen, mikä edistää kokonaistuottavuuden kasvattamista. Käytännössä se näkyy tietoisena yritystoiminnan kehittämisenä. Virheelliset päätökset vähenevät, yksikkökustannukset alenevat ja kannattavuus paranee. Kun prosesseja kehitetään maitotilayrityksen kokonaisuutta tukien, päästään parhaaseen tulokseen. Maitotilayrittäjiltä puuttuu systemaattisia apuvälineitä johtaa yritystään kokonaisvaltaisesti, mihin tarpeeseen tällä hankkeella vastataan.

Tutkimustietoon pohjautuen laaditaan maitotilayrityksen kokonaisvaltaisen johtamisen käsikirja. T\&Khankkeessa Kokonaisvaltaisella johtamisella kannattavuutta maidontuotantoon -tutkimuksen tulokset muunnetaan käytännön tarpeita palvelevaan muotoon. Kokonaisvaltaisen johtamisen käsikirja mahdollistaa päätöksien teon tutkitun tiedon, systemaattisen suunnittelun ja harkinnan pohjalta. Käsikirjan avulla maitotilayrittäjä voi tarkastella ja analysoida kehittämistoimien tarkoituksenmukaisuutta ja kannattavuusedellytyksiä luotettavalta pohjalta, mikä tuo maitotilayrittäjälle konkreettista apua yrityksensä menestyksekkääseen johtamiseen.

Hankkeen päätavoitteena on luoda kokonaisvaltaisen johtamisen käsikirja tutkimustiedon pohjalta ja tuottaa apuvälineitä maitotilayrityksen kokonaisvaltaiseen johtamiseen. Aineistoa hankitaan kirjallisuudesta, työpajatyöskentelyillä ja käsikirjan käytettävyyttä testaamalla. Maitotilayrityksen kokonaisvaltaisen johtamisen käsikirjan käytettävyyden parantamiseksi järjestetään työpajoja. Niissä käsikirjaa kehitetään maitotilayrittäjien ja maitoalan asiantuntijoiden ehdotusten pohjalta. Kokonaisvaltaisen johtamisen käsikirjaa testataan 10-15 maitotilayrityksessä. Palaute maitotilayrittäjiltä on erityisen tärkeää, jotta käsikirja saadaan vastaamaan heidän tarpeitaan. Käsikirjan hyödynnettävyyden parantamiseksi yhteistyötä tehdään myös meijereiden, ProAgrian ja Suomen Yrittäjäopiston asiantuntijoiden kanssa. Tavoitteena on, että maitotilayrittäjät kykenevät käsikirjan avulla johtamaan yrityksiään ja kehittämään tuotantoprosessejaan kokonaisvaltaisesti.

Asiasanat: maitotilayrittäjä, johtaminen, kannattavuus, tuottavuus

\section{Johdanto}

Maitotilayrittäjän toimintaympäristö, tuotantoteknologia, markkinat ja hallinnolliset päätökset muuttuvat sekä uutta tietoa tuotetaan, mikä tuo maitotilayrittäjälle tarpeen hankkia lisäosaamista. Maitotilayrittäjän on pystyttävä vastaamaan muutosten tuomiin haasteisiin, jotta yritystoiminnan edellytykset voidaan säilyttää. Maitotilayritystä on tarve johtaa strategisesti kokonaisuutena. Kokonaisvaltaisella johtamisella mahdollistetaan tuotantoprosessien ja toimintojen määrätietoinen ja systemaattinen johtaminen, mikä edistää kokonaistuottavuuden kasvattamista. Kun prosesseja kehitetään maitotilayrityksen kokonaisuutta tukien, päästään parhaaseen tulokseen. 
Maitotilayrityksen kokonaisvaltaisen johtamisen perustan muodostaa strategia, joka viedään toimintamallin avulla käytännön toimiksi ja työtehtäviksi. Strategisia vaihtoehtoja selvittäessään maitotilayrittäjän kannattaa vertailla ja analysoida vaihtoehtoisia toimintatapoja, jotta paras mahdollinen strategia kyetään valitsemaan. Kun strategia valitaan riittävän tiedon ja systemaattisten analyysien pohjalta, menestysstrategian löytämisen todennäköisyys paranee. Maitotilayrittäjälle kirjallisesta suunnittelutyöstä on hyötyä, sillä suunnitteluprosessi parantaa johtamisvalmiuksia. Se mahdollistaa myös uusien ajatusten synnyn. Ilman systemaattista suunnittelua ja konkreettisia malleja, virheellisten päätösten mahdollisuus kasvaa.

Maitotilayrittäjiltä puuttuu tällä hetkellä apuvälineitä johtaa yritystään kokonaisvaltaisesti. Kokonaisvaltaisella johtamisella kannattavuutta maidontuotantoon -hankkeen yhtenä tavoitteena on luoda kokonaisvaltaisen johtamisen käsikirja tutkimustiedon pohjalta ja tuottaa apuvälineitä maitotilayrityksen kokonaisvaltaiseen johtamiseen. Tässä artikkelissa kuvataan, miten Kokonaisvaltaisen johtamisen -malli (ks. Ryhänen ym. 2019) muunnetaan maitotilayrittäjien strategiaprosessia palvelevaan käsikirjamuotoon. Kokonaisvaltaisen johtamisen -käsikirja opastaa maitotilayrittäjää strategian laadinnassa, toteuttamisessa, maitotilayrityksen johtamisessa ja yritystoiminnan kehittämisessä. Se auttaa maitotilayrittäjää johtamaan maitotilayritystä kokonaisuutena ja tekemään perusteltuja päätöksiä sekä analysoimaan vaihtoehtoisia toimintatapoja.

\section{Materiaalit ja menetelmät}

Kokonaisvaltaisella johtamisella kannattavuutta maidontuotantoon -hankkeessa on selvitetty maitotilayritysten kokonaisvaltaisen johtamisen nykytilaa ja kehittämistarpeita. Kerätyn aineiston ja kirjallisuuden perusteella hankkeessa luotiin kokonaisvaltaisen johtamisen -malli (ks. Ryhänen ja Närvä 2019), joka muunnetaan maitotilayrittäjiä palvelevaan muotoon käsikirjaksi. Käsikirjan työstämisessä ja viimeistelyssä hyödynnetään kirjallisuutta sekä maitotilayrittäjien ja sidosryhmien edustajien näkemyksiä (Kuva 1). Hankkeessa järjestetään työpajoja, joissa käsikirjaa kehitetään maitotilayrittäjien ja maitoalan asiantuntijoiden ehdotusten pohjalta. Käsikirjaa testataan 10-15 maitotilayrityksessä, jotta käsikirja saadaan vastaamaan maitotilayrittäjien tarpeita. Käsikirjan hyödynnettävyyden parantamiseksi tehdään yhteistyötä meijereiden, ProAgrian ja Suomen Yrittäjäopiston asiantuntijoiden kanssa.

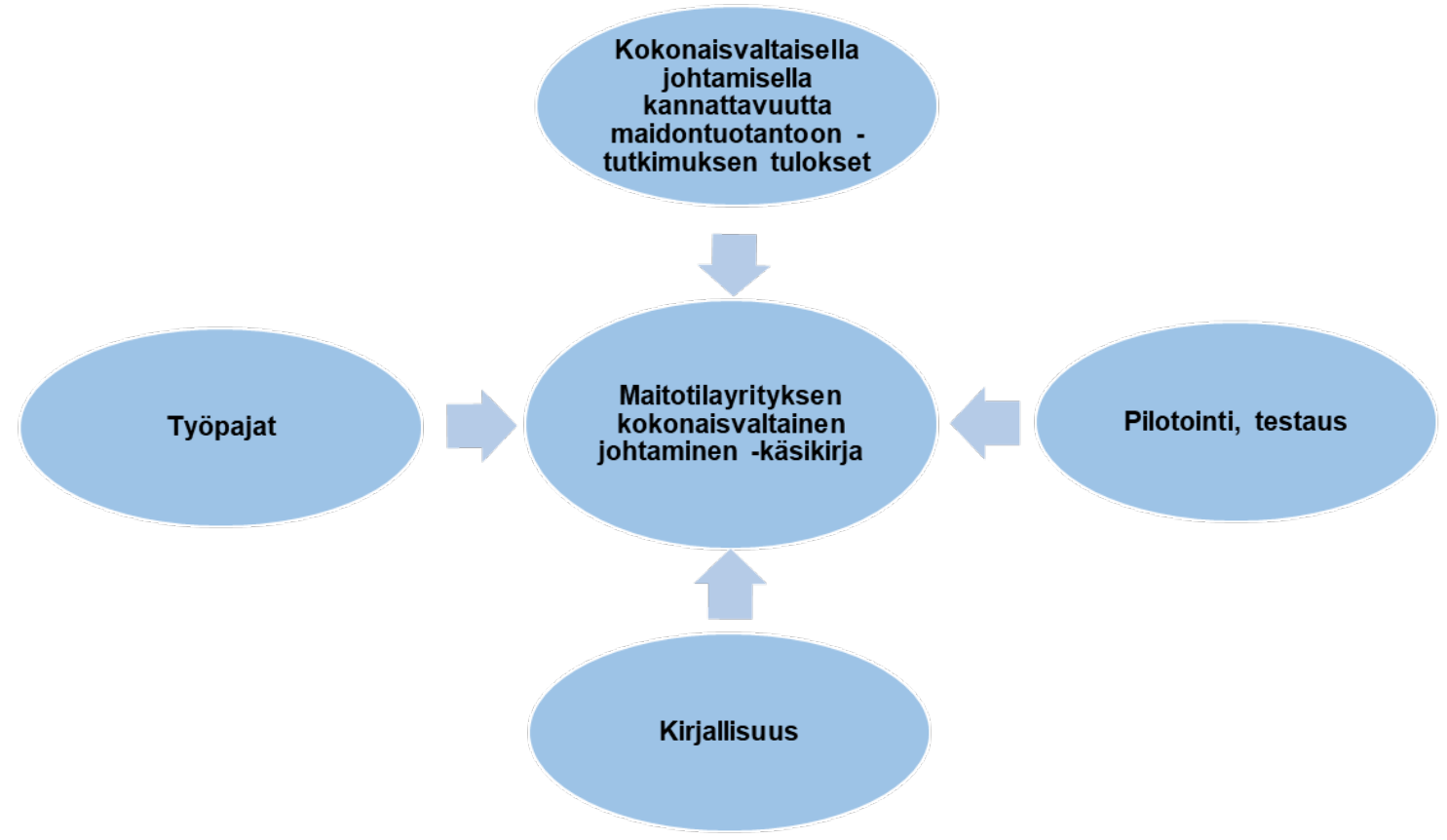

Kuva 1. Käsikirjan työstämisessä hyödynnettävät asiat. 


\section{Tulokset}

Kokonaisvaltaisen johtamisen käsikirja laaditaan niin, että se kannustaa maitotilayrittäjiä pohtimaan kokonaisvaltaisen johtamisen merkitystä kannattavuuden parantamisessa ja auttaa maitotilayrittäjiä selvittämään keskeisimpiä strategian laadintaan liittyviä kysymyksiä. Käsikirjassa esitetään toimintamallin luonnin perusteet ja strategian vienti käytännön toimiksi ja työtehtäviksi. Käsikirja jakautuu kolmeen eri osioon. Käsikirjan täyttäminen aloitetaan osiosta $\mathrm{A}$ ja edetään sen jälkeen osioon $\mathrm{B}$ ja sen jälkeen osioon C. Kyseessä on iteratiivinen prosessi, joten eri osioihin palataan uudelleen. Kuten kuvasta 2 huomataan, osiossa A laaditaan strategia. Tässä osiossa analysoidaan toimintaympäristöä ja maitotilayrityksen resursseja. Näiden pohjalta laaditaan synteesianalyysi ja muodostetaan missio. Tässä vaiheessa tehdään strategiset valinnat ja päätetään strategiset ja taloudelliset tavoitteet. Tässä vaiheessa tehdään myös strategiasuunnitelma ja päätetään, miten se toteutetaan.

\section{STRATEGIAN LAADINTA; OSIO A}

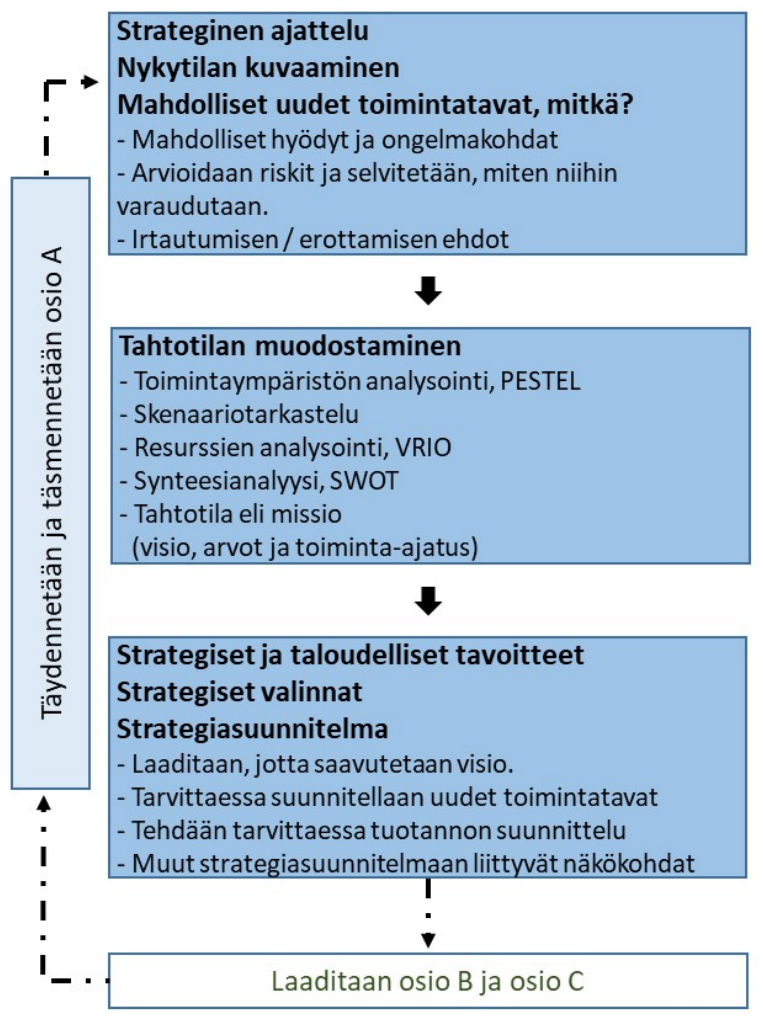

Kuva 2. Käsikirjan osion A sisältö

Osiossa B tahtotila ja strategiasuunnitelma muunnetaan toimintamallilla käytännön tehtäviksi (Kuva 3). Hyvä toimintamalli on riittävän tarkka, selkeä ja helposti ymmärrettävä ja se on käytännössä toteutettavissa.

Osiossa C toimintamalli viedään käytännön työtehtävien toteuttamiseen (Kuva 4). Tässä osiossa esitetään käytänteet, tekeminen, rutiinityöt, vuorovaikutus ja vastuut. Jokaisen on tiedettävä, mikä on hänen roolinsa ja vastuunsa strategian toteuttamisessa. Kaikkien kumppaneiden on osallistuttava strategian tekoon, jotta siihen sitoudutaan. Tässä vaiheessa päätetään käytännön töiden toteuttamisesta. 
TOIMINTAMALLIN LAADINTA; OSIO B

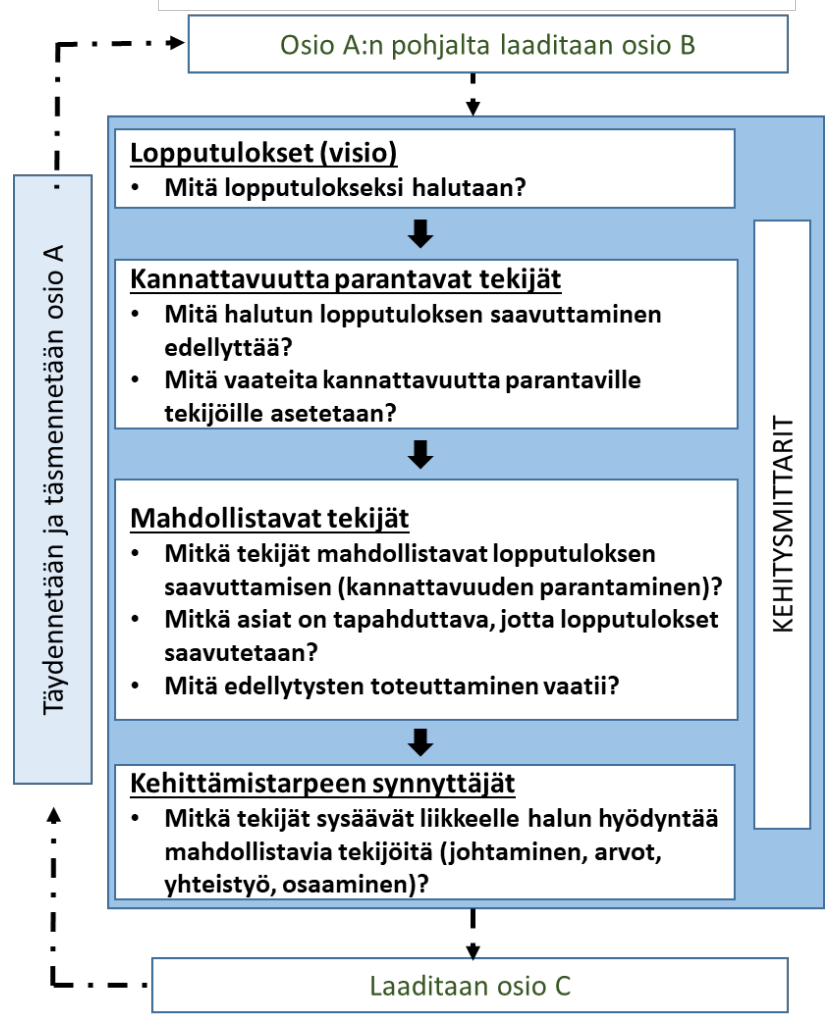

Kuva 3. Osion B sisältö

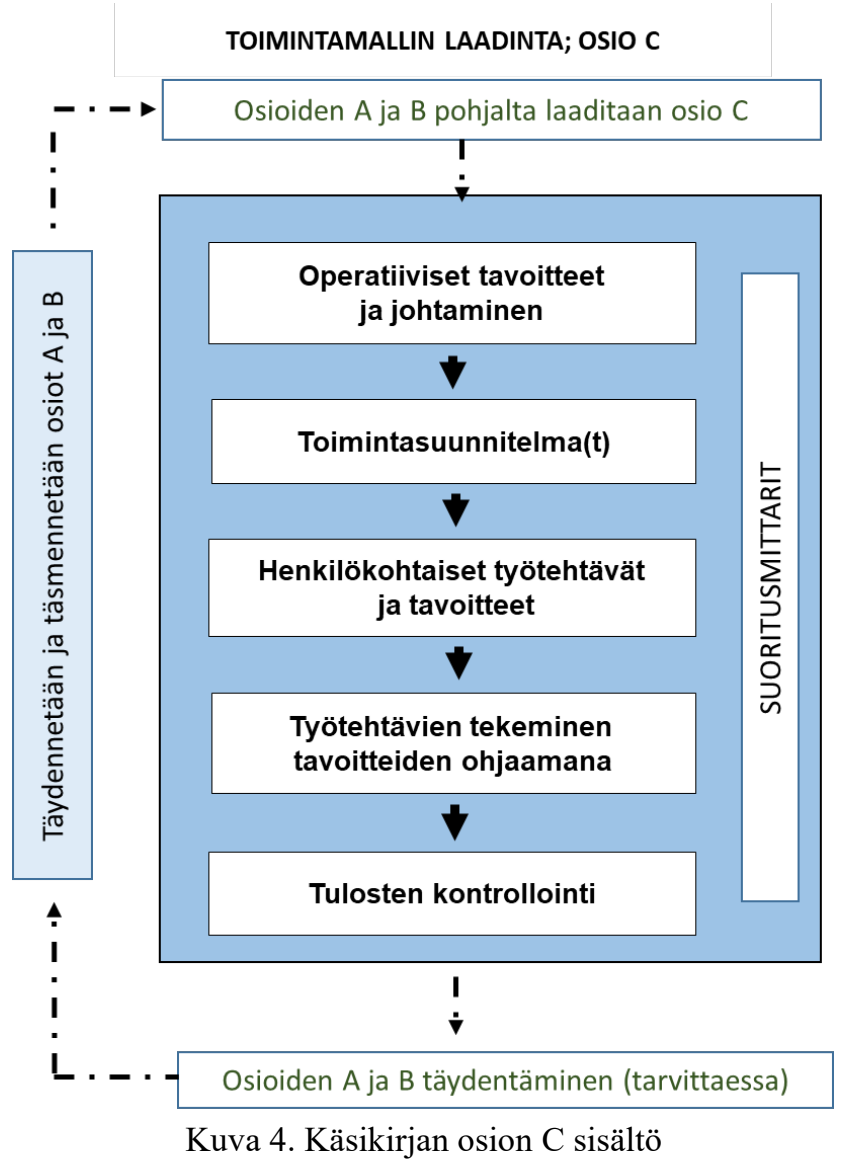


Kokonaisvaltaisen johtamisen käsikirjaan merkitään strategian toteuttamisen kannalta keskeiset asiat. Käsikirjan laadinnan laajuuteen ja syvyyteen vaikuttaa suunnittelun syvyys ja laajuus. Käsikirja rakentuu kuvissa 2-4 esitetyistä osioista. Osioissa esitetään tutkimuksen pohjalta (Ryhänen \& Närvä 2019) laadittuja malleja, esimerkkejä ja kysymyksiä.

\section{Johtopäätökset}

Kokonaisvaltaisella johtamisella kannattavuutta maidontuotantoon -hankkeessa laadittava käsikirja toimii jatkossa maitotilayrittäjän työkaluna kokonaisvaltaisen johtamisen suunnittelussa ja käytäntöön viennissä. Sen avulla maitotilayrittäjä pystyy hahmottamaan maitotilayrityksen toiminnan kokonaisuutena. Käsikirja tarjoaa rungon kokonaisvaltaiselle johtamiselle ja antaa viitekehyksen yritystoiminnan suunnittelulle. Se mahdollistaa strategisen ajattelun systemaattisen testaamisen. Se kannustaa maitotilayrittäjää selvittämään toimintaympäristöä ja sen muutospaineita, analysoimaan oman yritystoiminnan resursseja, tavoitteita, toimintatapoja, tuottavuutta, tehokkuutta ja kannattavuutta. Se auttaa ratkaisemaan, mitä kannattaa tehdä, missä järjestyksessä ja millä aikataululla. Lisäksi se auttaa viestimään maitotilayrittäjän ajatuksia tulevasta toiminnasta sidosryhmille.

\section{Kirjallisuus}

Ryhänen, M. \& Närvä, M. (toim.) 2019. Kokonaisvaltaisella johtamisella kannattavuutta maidontuotantoon. Seinäjoen ammattikorkeakoulun julkaisusarja A. Tutkimuksia 31.

Ryhänen, M., Rajakorpi, J., Närvä, M. \& Sipiläinen, T. 2019. Kokonaisvaltaisen johtamisen malli. Teoksessa: Ryhänen, M. \& Närvä, M. (toim.). 2019. Kokonaisvaltaisella johtamisella kannattavuutta maidontuotantoon. Seinäjoen ammattikorkeakoulun julkaisusarja A. Tutkimuksia 31: 117-165. 